\title{
Ügyfélelőnyök az Uniós Vámkódexben
}

\section{SZENDI Antal ${ }^{1}$}

\begin{abstract}
E tanulmány célja, hogy az olvasó megismerje azokat a gazdálkodókat érintő elönyöket, amelyek megtalálhatók az Uniós Vámkódexben. Mint az általában ismert, a vám olyan adójellegű fizetési kötelezettség, amelyet akkor kell fizetni, amikor egy áru egy másik országból bekerül az unió területére. A vámjogszabály azonban nem minden esetben ír elö konkrét fizetési kötelezettséget. Ténylegesen közterhet fizetni csak akkor kell, ha az áru azzal a céllal érkezik be, hogy az végleg bekerül az EU belső piacára. Az esetek jelentős részében azonban árubehozatal nem végleges szándékkal történik, hanem megmunkálás, feldolgozás céljából, így - véglegesség hiányában - fizetési kötelezettség sem keletkezik. A tanulmány azokat az eseteket mutatja be, amelyek kifejezetten kedvezőek a gazdasági szereplők számára.
\end{abstract}

Kulcsszavak: Uniós Vámkódex, közteher, árubehozatal, gazdasági szereplők

\section{Bevezetés}

A tanulmány címének értelmezése során felmerülhet a kérdés, hogy milyen ügyfélelőnyök lehetnek egy vámellenőrzés, illetve egy vámeljárás során? A kérdés megválaszolásához szükséges megismerni az Európai Unió vámrendszerének müködését, a téma szempontjából releváns folyamatait. Magyarország 2004-től az Európai Unió teljes jogú tagja, ezért figyelembe véve az uniós jog elsődlegességének elvét, csatlakozásunk óta nemzeti vámjogszabály helyett az Uniós Vámkódex (UVK) előírásait alkalmazzuk. ${ }^{2}$

Amennyiben az Európai Unióba egy tagállamnak nem minősülő országból vagy területről áru érkezik be, az szükségképpen vámellenőrzés alá esik. Tekintettel arra, hogy az Európai Unió egyben vámuniót ${ }^{3}$ is alkot, így a közösségi vámérdek szempontjából valójában mindegy, hogy melyik tagállamba érkezik meg az áru. A vámellenőrzés a vámhatóságok által elvégzett konkrét intézkedések, amelyek célja az, hogy biztosítsák az unió vámterülete és az e területen kívüli országok vagy területek között szállított áruk beléptetését, kiléptetését, árutovábbítását, szállítását, tárolását és meghatározott célra történő felhasználását, valamint a nem uniós áruknak és a meghatározott célra

SZENDI Antal dr., püőr. ezredes, mesteroktató, NKE RTK, Vám-és Pénzügyőri Tanszék

Antal SZENDI Customs Colonel, Master Instructor, NUPS Faculty of Law Enforcement, Department of Customs and Finance Guard, NUPS Faculty Law Enforcement Department of Costums and Finance Guard https://orcid.org/0000-0001-5177-6376; szendi.antal@nav.gov.hu

2. Szalayné Sándor (2003) 210.

3 Az Európai Gazdasági Közösséget létrehozó Rómában 1957. március 25-én aláírt szerződés (római szerződés) vámunióról szóló 1. szakasz 12. bekezdése. Forrás: https://eur-lex.europa.eu/legal-content/HU/TXT/?uri=celex:11957E/ TXT (2019. 09. 20.) 
történő felhasználás alatt lévő áruknak az unió vámterületén belüli jelenlétét és szállítását szabályozó vámjogszabályoknak és a más jogszabályoknak való megfelelést. ${ }^{4}$

A fentiek alapján a tagállami vámhatóságok az áruk behozatala, illetve kivitele során elvégezhetnek minden olyan ellenőrzést, ${ }^{5}$ amit szükségesnek tartanak ahhoz, hogy az Uniós Vámkódexben megfogalmazott ${ }^{6}$ küldetésüknek meg tudjanak felelni. A vámhatóságok felügyelik elsődlegesen az unió külkereskedelmét, hozzájárulnak ezzel a tisztességes és nyitott kereskedelemhez. Tevékenységükkel lehetővé teszik a közös kereskedelempolitika és azzal összefüggő más közös uniós politikák végrehajtását, valamint elősegítik az ellátási láncok átfogó biztonságát. A tagállami vámhatóságok így olyan intézkedéseket hoznak, amelyek célja különösen:

1. az unió és tagállamai pénzügyi érdekeinek védelme;

2. az unió védelme a tisztességtelen és jogellenes kereskedelemmel szemben, a jogszerü üzleti tevékenység támogatása mellett;

3. az unió és lakói biztonságáról és védelméről, valamint a környezetvédelemről való gondoskodás, szükség szerint más hatóságokkal szorosan együttmúködve; és

4. megfelelő egyensúly fenntartása a vámellenőrzések és a jogszerű kereskedelem megkönnyítése között. ${ }^{7}$

Témánk szempontjából a 4. pontban foglaltaknak van jelentősége, mert a kereskedelmi könnyítések megvalósulása jelentős részben a vámszabályok ügyfélbarátságán múlik. Az Uniós Vámkódex rendelkezései arra a kereskedelemben előforduló alapkérdésre épülnek fel, hogy az áru behozatala milyen célból történik az Európai Unió területére. A cél egyaránt lehet végleges vagy ideiglenes. Amennyiben végleges céllal történik a behozatal, a fő szabálytól eltérően a vámjogszabály arra is lehetőséget ad, hogy az áru után ne keletkezzen azonnal vám- és egyéb közteherfizetési ${ }^{8}$ kötelezettség. Amennyiben a behozatal ideiglenes jelleggel történik, ${ }^{9}$ az esetben vagy nem keletkezik semmilyen fizetési kötelezettség, vagy csak az esedékes vám töredékét kell havonta megfizetni. Külön figyelmet igényelnek azok a gazdálkodók, amelyek meghatározott feltételek mellett külön kedvezményekben részesülhetnek eljárásaik során. Számos ilyen kedvezmény létezik, azonban a legfontosabb az Engedélyezett Gazdálkodói (AEO) tanúsítvány kiadása, amely az ellenőrzések számának észszerű csökkentését teszi lehetővé. ${ }^{10}$ Az említett EU-program és a hozzá hasonló elveket követő programok, mint például

\footnotetext{
4 Az Európai Parlament és a Tanács 952/2013/EU rendelete (2013. október 9.) az Uniós Vámkódex létrehozásáról (UVK) 5. cikk 3. pont.

5 Az ellenőrzés lehet külső, belső áruvizsgálat, a szállítmányok, szállítóeszközök, csomagok megvizsgálása, sértetlenségéről való meggyőződés.

UVK 3. cikk.

UVK 3. cikk.

8 A tagállamok által beszedett vámok 80\%-a az Európai Unió költségvetését illeti meg, míg a fennmaradó 20\% a tagállamot illeti. Az egyéb teher pedig azokat az adókat jelenti, amelyeket a vámmal együtt kell kivetni és beszedni, és tagállami jogalkotási hatáskörbe tartoznak.

9 Lásd lejjebb: ideiglenes behozatal és aktív feldolgozás.

10 Schramm (2015) 59-68.
} 
az Amerikai Egyesült Államok C-TPAT ${ }^{11}$ programja tartósan alacsony kockázatú gazdálkodók számára biztosít előnyöket. ${ }^{12}$

\section{Vámeljárások}

Figyelemmel a bevezetőben írtakra áttekintem az egyes vámeljárásokat és azok bemutatása során külön kiemelem a témánk szempontjából lényeges jellemzőket.

\section{Szabad forgalomba bocsátás}

A szabad forgalomba bocsátás az egyik legismertebb vámeljárás, amely az importáruk forgalomba hozatalát teszi lehetővé. A vámeljárás lefolytatását követően az áruk vámjogi státusza ${ }^{13}$ megváltozik, mert uniós áruvá válnak. A vámkezelés során - itt eltekintve a vámmentességek eseteitől - vám- és egyéb teherfizetési kötelezettség keletkezik, amelyre a vámjogszabály nagyon méltányos, 10 nap fizetési határidőt állapít meg annak ellenére, hogy jogintézmény elnevezése: azonnali vámfizetés. További kedvezményeket is találhatunk a jogszabályban a fizetési határidőkre vonatkozóan. A halasztott vámfizetés jogintézménye lehetővé teszi, hogy a gazdálkodó a fizetési kötelezettségét 30 napon belül rendezze, vagy amennyiben heti összevonási engedéllyel rendelkezik, a tárgyhetet követô negyedik hét péntekéig fizesse meg a közterheket. Mindezeken túlmenően további lehetőség, hogy havi összevonás esetén a tárgyhónapot követő hónap 16. napjáig tegyen eleget az ügyfél fizetési kötelezettségének. ${ }^{14}$ Azt gondolom, hogy jelentős könnyítés a kereskedők számára, hogy akár 10, 26, 30, illetve 45 nap fizetési haladékot kapnak a vámfizetésre, hiszen előbb forgalomba hozhatják az árukat, és annak bevételéből egyenlíthetik ki a közterheket.

Külön jelentősége van a szabad forgalomba bocsátásnál az egyszerűsített eljárásoknak is. ${ }^{15}$ Ennek lényege abban áll, hogy nem kell minden egyes szállítmányt különkülön vámkezelni, hanem egy meghatározott időszak alatt beérkezett nem uniós árukat egyszerre kell - egy eljárásban - vámeljárás alá vonni. Nem szabad elfeledkeznünk a kockázatelemzés nyújtotta előnyökről sem. ${ }^{16} \mathrm{Az}$ elektronizáció nagyarányú fejlődése ráadásul újabb lehetőséget nyitott meg a kockázatelemzés és -kezelés számára, amely

\footnotetext{
Vám és Kereskedelmi Együttmúködés a Terrorizmus Ellen.

Csaba (2012) 69-77.

Az áru lehet uniós, illetve nem uniós áru.

Suba-Szendi (2018) 94-95.

Wagner (2019) 107-109.

Lásd: 2006. évi XLI. törvény a vámeljárások egyszerűsítéséről és összehangolásáról szóló, Kiotóban, 1973. május 18án kelt nemzetközi egyezmény Brüsszelben, 1999. június 26-án létrehozott Módosító Jegyzőkönyvének kihirdetéséről. Az egyezmény mellékletének a vámellenőrzésekről szóló 6. fejezet 6.3. pontjában foglalt kötelező rendelkezés a vámhatóságok számára kockázatkezelés alkalmazását írja elő a vámellenőrzések végrehajtása során. A felülvizsgált Egyezményt az Európai Unió is implementálta az Európai Unió Tanácsának 2003/231/EK határozata az Európai Közösségeknek a vámeljárások egyszerűsítéséről és összehangolásáról szóló nemzetközi egyezmény (kiotói egyezmény) módosító jegyzőkönyvéhez való csatlakozásról (2003. március 17.).
} 
hozzájárul a kockázatos szállítmányok pontosabb azonosításához, illetve tágabb értelemben a bevételi hatóságok erőforrásainak hatékonyabb felhasználásához. ${ }^{17}$

\section{Ideiglenes behozatal}

Az ideiglenes behozatali eljárás lehetővé teszi az újrakivitelre szánt nem uniós áruk behozatalát az unió vámterületére teljes vagy részleges mentesség mellett. Ez esetben is történik árubehozatal, tehát elvileg vám- és egyéb teherfizetési kötelezettség keletkezik. Az összeget azonban nem kell megfizetni, mivel az ügyfél szándéka nem arra irányult, hogy az áru végleg az Európai Unió területén maradjon. Az első esetben (teljes vámmentesség) egyáltalán nem keletkezik semmilyen fizetési kötelezettség, a másik esetben igen, azonban az nem számottevő. Egyéb esetben is találunk könnyítéseket a jogintézmény esetében, hiszen nem kell például kereskedelempolitikai intézkedéseket alkalmazni az áruk tekintetében (hacsak azok nem tiltják meg a nem uniós áru beléptetését). ${ }^{18}$

Az ideiglenes behozatali eljárásban az áruknak változatlan állapotban kell maradniuk, kivéve a használatból eredő szokásos értékcsökkenést.

Az eljárás keretében megengedett a javítás és a karbantartás, beleértve a nagyjavítást és a beállításokat, valamint az áru állagának megőrzését és a használatára vonatkozó műszaki előírásoknak való megfelelés biztosítását célzó intézkedések megtételét is. Az ideiglenes behozatal közvetve nyújt segítséget a gazdasági élet fejlődéséhez. Ugyanis a nemzetközi rendezvényekre, konferenciákra, kiállításokra ideiglenes jelleggel beérkező kiállítási tárgyak után nincs fizetési kötelezettség, azonban mégis gazdasági hasznot hozhat, ugyanis egy sikeres kiállítás és bemutató után számos külkereskedelmi szerződés jöhet létre. Elmondhatjuk, hogy a vámszabályok itt is kifejezett segítséget nyújtanak az érintett gazdálkodóknak. A napi életben gyakran előforduló esetekben - forgalomgyorsítási érdekből is - a kereskedelmi szállítóeszközök (tehergépkocsik, vasúti kocsik, repülőgépek), valamint raklapok, szállítótartályok ${ }^{19}$ alakiság nélkül teljes vámmentességgel lépik át a vámhatárt. Az adminisztrációs terhek megszüntetése, az ezzel megtakarított idő szintén a gazdasági élet szereplőinek a javára válik. Szükséges kiemelni továbbá, hogy az ideiglenesen behozott áruk - alapszabályként - 24 hónapig maradhatnak a vámunió területén, sőt egyes különleges esetben ez a határidő 10 évre is meghosszabbodhat. ${ }^{20}$ A gazdasági élet napi ritmusát tekintve ez elegendő idő ahhoz, hogy az ideiglenes behozatal elérje a célját. Ritkább eset, amikor egyéb célból érkezik be ideiglenes jelleggel áru az unióba. Ilyenkor a részleges vámmentességet kell alkalmazni, ami azt jelenti, hogy nem a kiszabott vám és általános forgalmi adó teljes ösz-

\footnotetext{
Csaba (2018) 47-57.

UVK 250. cikk.

A Bizottság (EU) 2015/2447 végrehajtási rendeletének (VA) 208-236. cikke tartalmazza az árukört.

Lux (2017) 128.
} 
szegét, hanem annak mindössze 3\%-át kell havonta úgynevezett „használati vámként” megfizetni. ${ }^{21}$

\section{Vámraktározás}

A vámraktározási eljárás a tanulmány tekintetében kiemelt helyet foglal el. Ez az a vámeljárás, amely talán a legtöbb elönyt biztosítja a gazdálkodók számára. Mindenekelőtt azt teszi lehetővé, hogy behozzák a nem uniós árukat az Európai Unióba, betárolhatják vámraktárba anélkül, hogy bármilyen közteherfizetési kötelezettségük keletkezne. Ez a gyakorlatban azt jelenti, hogy a beérkezést követően akkor hozza forgalomba az ügyfél az áruját, amikor akarja, azaz a legjobb gazdasági feltételek mellett tudja majd értékesíteni. Magához a vámraktározási eljáráshoz semmilyen külön engedély nem kell, sőt az árukra vonatkozó kereskedelempolitikai intézkedéseket sem kell alkalmazni, mivel az áru nem kerül forgalomba a szabadpiacon. Természetesen, ha az áru beléptetése az unió területére eleve tiltott, az esetben vámraktározásról sem lehet szó. ${ }^{22}$ Képzeljünk el például egy építőanyag-kereskedő gazdálkodót, aki kedvezményes áron tud beszerezni faanyagot. Köztudott, hogy az építkezési kedv a hideg hónapokban kevésbé intenzív, tehát az érintett termékkör is kevésébe fogy. A tavasz kezdetével azonban mindez a visszájára fordul, és megnő a kereslet az építőanyag iránt. Ezen a ponton jelentkezik a vámjog biztosította előny: az ősszel behozott építőanyagot vámraktárban tárolhatta a tulajdonos. Ahogy a kereslet indokolja, nyomban szabad forgalomba tudja hozni, megfelelő áron értékesítve a faanyagokat.

A továbbiakban meg kell említeni két másik fontos tényezőt is: a határidôkre és magára a tárolásra vonatkozó rendelkezéseket. A határidők tekintetében fontos, hogy a vámjogszabály nem szabályozza a raktározás idôtartamát, tehát elvileg bármeddig lehet az áru a vámraktárban. ${ }^{23}$ Ezzel is a lehető legszélesebb cselekvési szabadságot biztosítja a gazdálkodó számára. Az más kérdés, hogy alapvetően a gazdasági életben nem azért történik az áruk behozatala, hogy azok vámraktárban maradjanak. Magára a tárolásra vonatkozóan is többféle lehetőséget kínál fel a szabályozás. A gazdálkodó választhat a vámraktártípusok között aszerint, hogy az üzleti tervéhez melyik áll közelebb. Így tárolhatja az áruját I. típusú vámraktárban (ahol a felelősség az üzemeltetóé), II. típusú vámraktárban (ahol viszont a felelősség a beraktározóé), III. típusú vámraktárban (amelyet a vámhatóság üzemeltet), illetve létesíthet saját maga is magánvámraktárt. A fentieken túlmenően elvégezhet minden olyan múveletet, amely nem eredményezi az áru állagának a megváltozását, azt csak fenntartani, illetve javítani lehet. Mindezeket figyelembe véve elmondható, hogy a vámraktározási vámeljárás tulajdonképpen

\footnotetext{
21 Ezen szabály a gyakorlati alkalmazása azt jelenti, hogy egy áru legfeljebb 33 teljes és egy megkezdett hónapig maradhat ideiglenes behozatalban.

22 UVK 237. cikk (1) bekezdés.

${ }^{23}$ Természetesen veszélyes, speciális áruk tekintetében korlátozható a raktározás ideje, amennyiben az veszélyt jelenthet az emberekre, állatokra, növényekre, illetve a környezetre.
} 
egy speciális fizetési halasztást is jelent. Csak akkor kell a vámot és az egyéb terhet megfizetni, ha az áru ténylegesen forgalomba kerül, előtte azonban korlátlan ideig tárolható az Európai Unió területén.

\section{Aktív feldolgozás}

Az aktív feldolgozás - mint az az elnevezésből is kitűnik - olyan különleges vámeljárás, amely lehetővé teszi, hogy a nem uniós árukat az unió vámterületén egy vagy több feldolgozási műveletnek vessék alá. Ha beérkezik az áru egy harmadik országból (általában alapanyag vagy félkész termék formában), majd az unióban feldolgozzák, és ezt követően a végtermék vissza- vagy kiszállításra kerül egy másik országba, akkor az ilyen célból beérkezett áruk után nem kell behozatali vámot és egyéb terhet fizetni. Kereskedelempolitikai intézkedések sem vonatkoznak rájuk, mivel - alapszabályként - nem kerülnek forgalomba a közös vámterületen. (Ha a későbbiekben mégis, akkor a szabad forgalomba bocsátás vámeljárás alkalmazása ad erre lehetőséget. ${ }^{24}$ Tehát beérkezik egy áru vám- és általánosforgalmiadó-fizetési kötelezettség nélkül, majd ugyanezt az árut megváltozott állapotban ${ }^{25}$ visszaszállítják külföldre. Az áru állagváltozáson esett át, azaz dolgoztak vele belföldön, így a munkahelyteremtô hatás is járulékos ügyfélelőnyként értékelhető.

Feldolgozási múveletek alatt megmunkálást, összeállítást, össze- és szétszerelést, hozzáillesztést, javítást ${ }^{26}$ és megsemmisítést értünk. Feldolgozási mûveletnek minősül továbbá olyan áruk felhasználása is, amelyek ugyan nem épülnek be a végtermékbe, de lehetővé teszik, vagy megkönnyítik azok előállítását.

Az aktív feldolgozási eljárás - a megsemmisítés, javítás, gyártási segédanyag felhasználása kivételével - csak olyan esetekben alkalmazható, ha az eljárás alá vont áruk a feldolgozott termékekben beazonosíthatók. A külkereskedelmi ügyletek sokféleségére jellemzően, ez esetben is több lehetőség közül választhat a gazdálkodó, hogy milyen szerződés alapján érkezik be a nem uniós áru. Elsőként említhető ezek közül a bérmunkaügylet, amelynek során a beérkező nem uniós áru (alapanyag, félkész termék) a külföldi fél tulajdonában marad, a belföldi gazdálkodó azért nem fizet. Bérmunkaszerződés alapján elvégzik a szükséges tevékenységet, amelyért a külföldi fél bérmunkadíjjal tartozik. A következő lehetőség a feldolgozásos ügylet, amelynek esetében a feldolgozást végző a vételárat megfizeti a külföldi félnek, ezt követően már mint tulajdonos dolgozza fel azt, és megváltozott állapotban kiszállítja a közösségi vámhatáron túlra. Harmadik lehetőség az export/import aktív feldolgozás, amely a nem uniós áruknak a termék feldolgozott állapotban történő kiszállítása előtt történik. Negyedik lehetőség az úgynevezett import/export aktív feldolgozás, amikor

\footnotetext{
UVK 256. cikk.

25 Vámjogi értelemben a „megváltozott állapot” azt jelenti, hogy az árubesorolás (azaz a termék vámtarifaszáma) megváltozik.

26 A javítás olyan művelet, amelynek eredményeként az eredeti rendeltetésre alkalmatlanná vált termék arra újra alkalmassá válik.
} 
a helyettesítő áruból készült el a végtermék és az előzetesen kivitelre kerül, de az importáru csak a kiszállítást követően érkezik be.

A helyettesítő áru ${ }^{27}$ olyan uniós áru, amely az importáru helyett kerül felhasználásra a végtermék elkészítése során. Ebből következik, hogy a helyettesítő árunak ugyanolyannak kell lennie, mint az importárunak, így különösen meg kell egyezni a tarifális besorolásuknak (a vámtarifaszám első nyolc számjegye azonos kell legyen), azonos műszaki tulajdonságokkal kell rendelkezniük és a minőségüknek is azonosnak kell lenniük.

Az aktív feldolgozás vámeljárás keretében behozott nem uniós árukkal el kell számolni. Fő szabályként az elszámolás a végtermék újrakivitelével ${ }^{28}$ valósul meg. Az aktív feldolgozási eljárást lezárja az áru valamilyen más vámeljárás alá vonása is. Amennyiben kérik a szabad forgalomba bocsátást, úgy a vám- és egyéb teher összegét meg kell állapítani és az általános szabályok szerint meg kell fizetni.

Azonban ha a szabad forgalomba kerülés esetén nem keletkezik vámtartozás (vagyis a vámtarifaszámhoz tartozó vámtétel $0 \%$ ), nem szükséges külön árunyilatkozatot benyújtani, hanem elegendő adónyilatkozatot tenni. Az aktív feldolgozás engedélyese minden naptári hónapot követő 10. napig köteles a fent említettek alkalmazása során az adóterhek megállapításához szükséges adónyilatkozatot benyújtani az adófizetési kötelezettség keletkezésekor az engedélyben megjelölt vámhivatalnál. Nem kell benyújtania az áfafizetési kötelezettség megállapításához szükséges adónyilatkozatot annak a gazdálkodónak, aki rendelkezik az áfa önadózással történő megállapítására jogosító engedéllyel, és egyéb adófizetési kötelezettsége a vámhatóság felé nem keletkezik.

$\mathrm{Az}$ engedélyesnek, az áruk megmunkálásával, feldolgozásával járó tevékenységet végző személynek a vámhatóság által jóváhagyott formában meghatározott nyilvántartást kell vezetnie.

$\mathrm{Az}$ aktív feldolgozási tevékenység végzését a vámhatóság - a gazdálkodó kérelmére - engedélyezi. Az engedély kiadásához a következő konjunktív feltételeknek kell megfelelnie a kérelmezőnek:

1. A tevékenység végzését az unió vámterületén letelepedett személy kérelmezheti. Indokolt esetben engedélyezhető az unió vámterületén kívül letelepedett személy részére is, ekkor az az illetékes vámhatóság, ahol az árut először fel fogják dolgozni.

2. Az esetlegesen felmerülő vámtartozás és egyéb terhek összegének mértékéig biztosítékot kell nyújtani.

3. További követelmény, hogy a végtermékben a feldolgozott áru azonosítható legyen.

4. Amennyiben helyettesítő árut kíván felhasználni, az erre vonatkozó szabályokat be kell tartania a kérelmezőnek.

27 Dézsi-Zoltay (2016) 59.

28 Az újrakivitelt meg kell különböztetnünk a kiviteltől. Újra kivinni vámjogi értelemben csak nem uniós árut, kivinni viszont csak uniós árut lehet. Az újrakivitel szót akkor alkalmazza a jogszabály, amikor a korábban beérkezett nem uniós árut ismételten vissza- vagy kiszállítanak egy harmadik országba. 
A fentiekből megállapítható, hogy a vámjogi szabályozás ez esetben is kifejezetten gazdálkodóbarát rendelkezéseket tartalmaz. A könnyítések közvetve a munkahelyteremtéshez is hozzájárulnak úgy, hogy egy alapadminisztrációs eljárás lefolytatásán kívül semmilyen egyéb költségekkel járó kötelezettséget nem tartalmaz.

\section{Nem vámeljárásokhoz kapcsolódó ügyfélelönyök}

Az Uniós Vámkódexben további előnyös lehetőségeket biztosítanak a gazdasági társaságok számára, amelyeket jogszerűen vehetnek igénybe.

\section{Az árunyilatkozat}

A konkrét vámeljárásokon túl azonban más vámjogi intézmények mögött is számos - ügyfeleknek kedvező - vámigazgatási intézkedések és eljárások rejlenek. Ilyen jogintézmény például az árunyilatkozat is. ${ }^{29} \mathrm{Az}$ árunyilatkozat benyújtására vonatkozó szabályok alkalmazása attól függ, hogy az árunyilatkozat benyújtása normál, vagy egyszerűsített eljárás keretében történik-e. Normál eljárásban az árunyilatkozat személyesen kerül benyújtásra a nyilatkozattevő vagy a vámjogi képviselő által. A vámhatóság képviselője jelen van az eljárásban, amely a vámhatóság hivatali helyiségében vagy az általa kijelölt helyen történhet.

1. Egyszerüsitett eljárásban a bizalmi elv érvényesül, ezért a benyújtásakor nem kell, hogy a vámhatóság jelen legyen. Amennyiben az ügyfél kérelmére a vámhatóság engedélyezte az egyszerűsített eljárás alkalmazását, úgy az alábbi módozatok alkalmazására van lehetőség:

2. Egyszerüsített árunyilatkozat ${ }^{30}$ esetén a árunyilatkozat adatai hiányosak, vagy nincs csatolva valamennyi okmány.

3. Eltérô vámtarifaalszámok alá tartozó árukra vonatkozó árunyilatkozatok ${ }^{31}$ esetén a nyilatkozattevő kérelmére engedélyezheti a vámhatóság, hogy a legmagasabb vámtételú áru vámtarifaszáma alapján vessék ki a vámot az egész szállítmányra. Ez nem vonatkozik azokra az árukra, amelyekre valamely korlátozás vagy tilalom van hatályban, illetve a jövedéki termékekre.

4. Központi vámkezelésre vonatkozó árunyilatkozatok ${ }^{32}$ a vámhatóság engedélyével alkalmazhatók. Az árunyilatkozatot a letelepedés helyén illetékes vámhivatalhoz kell benyújtani, míg a vám elé állítás másik vámhivataloknál történhetett meg.

\footnotetext{
Suba-Szendi (2018) 24-25.

UVK 166. cikk.

UVK 177. cikk.

UVK 179. cikk.
} 
Bejegyzés a nyilatkozattevő nyilvántartásába ${ }^{33}$ a vámhatóság engedélyével történhet. Ha a nyilatkozattevő nyilvántartásába bejegyzés formájában nyújt be árunyilatkozatot, az árunyilatkozat a bejegyzés pillanatában elfogadottnak tekintendő.

Áttekintve az árunyilatkozatra vonatkozó rendelkezéseket, megállapítható, hogy a vámjogszabályban foglalt lehetőségek alkalmazása alapján nem szükséges minden egyes beérkezett szállítmány után külön-külön árunyilatkozatot benyújtani. Lehetőség nyílik arra, hogy meghatározott idôtartam alatt beérkező árukra csak egy árunyilatkozatot nyújtson be az ügyfél. Ezzel jelentős időmegtakarítás érhető el, valamint az adminisztrációs teher is csökken. Az ügyfél elektronikus úton is előterjesztheti az árunyilatkozatokat, ami a gyakorlatban azt jelenti, hogy ma már az ügyfél-vámhatóság közötti kommunikáció szinte kizárólag elektronikus úton zajlik. ${ }^{34}$ Természetesen ez esetben is lehetősége van a vámhatóságnak konkrét ellenőrzést tartani.

\section{Átmeneti megörzés}

Az átmeneti megőrzés a nem uniós áruk azon helyzete, amikor azokat a vám elé állításuk és a vámeljárás alá vonásuk vagy újrakivitelük közötti időszakban vámfelügyelet ${ }^{35}$ alatt tárolják ideiglenes jelleggel. A definícióból az következik, hogy az átmeneti megőrzés nem vámeljárás, hanem egy olyan vámigazgatási intézkedés, amelynek célja megfelelő idő biztosítása az ügyfélnek arra, hogy eldöntse, milyen vámeljárásban kéri részesíteni az adott árut.

A nem uniós áruk vám elé állításukkor - a törvény erejénél fogva - átmeneti megőrzésbe kerülnek. A vám elé állított nem uniós áruk tekintetében átmeneti megőrzési árunyilatkozatot kell benyújtani legkésőbb az áruk vám elé állításának időpontjában, amely tartalmazza az átmeneti megőrzésre irányadó rendelkezések foganatosításához szükséges összes adatot.

A vámhatóságok átmeneti megőrzési árunyilatkozatként elfogadhatnak hivatkozást a szóban forgó árura vonatkozóan benyújtott bármely belépési gyưjtő árunyilatkozatra, szükség szerint kiegészítve az átmeneti megőrzési árunyilatkozaton feltüntetendő adatokkal, vagy manifeszt okmányt, illetve más fuvarokmányt, ha azok tartalmazzák az átmeneti megőrzési árunyilatkozaton feltüntetendő adatokat.

A vámhatóságok továbbá kereskedelmi, kikötői vagy szállítási informatikai rendszerekben tárolt adatokat elfogadhatnak az átmeneti megőrzési árunyilatkozatok

33 UVK 182. cikk.

34 Hazánkban a vámigazgatási eljárások elektronizálása jogszabályok szintjén 1996-ban kezdődött, amely a konkrét eljárások elektronizációjában 2000. július 1-től kezdődően öltött testet az egyszerűsített vámeljárások területén. Mára az elektronikusan benyújtott árunyilatkozatok döntő részarányt képviselnek. Vö. Suba (2019) 205.

35 A vámfelügyelet olyan vámigazgatási intézkedés, amelynek célja a vámjogszabályokban - illetve amennyiben ez szükséges, egyéb jogszabályokban foglalt rendelkezések betartása. Az áru mindaddig vámfelügyelet alatt marad, ameddig annak vámjogi státuszának meghatározásához szükséges. A nem uniós árut addig kell vámfelügyelet alatt tartani, ameddig annak vámjogi státusza meg nem változik, illetve ameddig ki nem viszik az unió vámterületéről. Uniós áru tekintetében a vámfelügyelet addig tart, ameddig arra az áruk vámjogi státuszának meghatározásához szükség van. A vámfelügyelet megvalósulásának feltételei: 1. a nyilvántartásba vétel, 2. vámbiztosíték nyújtása, 3. az áru azonosságának biztosítása. 
benyújtásához. Az átmeneti megőrzési árunyilatkozatot érkezési értesítésnek, vagy az áruk vám elé állítása céljára is felhasználhatók, amennyiben azok eleget tesznek a jogszabályban meghatározott feltételeknek.

$\mathrm{Az}$ átmeneti megőrzési árunyilatkozatot a vámhatóságoknak meg kell őrizniük, hogy ellenőrizhessék, hogy az érintett árukat a későbbiekben vámeljárás vagy újrakiviteli eljárás alá vonták-e. A nyilatkozattevő számára ilyen irányú kérelem esetén meg kell engedni, hogy az átmeneti megőrzési árunyilatkozat benyújtását követően annak egy vagy több adatát módosítsa. A módosítás nem eredményezheti azt, hogy az árunyilatkozat az eredeti áruktól eltérő árukra vonatkozzon.

Az átmeneti megőrzés szintén olyan célokat szolgál, amelyek kifejezetten ügyfélbarát vámigazgatási intézkedésnek értékelhetők. A legfontosabb előnye a jogszabályban rögzített határideje, ${ }^{36}$ amely legfeljebb 90 nap. Három hónapi időintervallumnak elegendőnek kell lennie annak eldöntésére, hogy egy beékezett nem uniós áruval mit is kezdjen az adott gazdálkodó. Az uniós vámrendszer áttanulmányozása során még számos olyan rendelkezést találhatunk, amely a gazdálkodókat segíti abban, hogy - a jogszerúség szem előtt tartásával - minél korábban hozzájuthassanak az áruikhoz, és azokat vagy értékesíteni, vagy a gazdasági célok érdekében megfelelően hasznosítani tudják.

\section{Összefoglalás}

Mint az előzőekben láttuk, a közösségi vámjog számos ponton tartalmaz a külkereskedelemben részt vevő gazdasági társaságok számára jogszerűen igénybe vehető előnyöket. Ezeknek célja a kereskedelem elősegítése, könnyítése, a vámügyi formalitások egyszerűsítése, az ügyfelek és a vámhatóságok közötti együttműködés elősegítése. A kedvezmények egy része konkrét vámeljáráshoz kötődik, amelyek során a vám- és egyéb (adó)terhek megfizetésére kapnak a gazdálkodók pontosan meghatározott időkedvezményt, könnyebben finanszírozhatóvá, illetve tervezhetőbbé téve azt. Az időkedvezmény lehetővé teszi azt is, hogy kedvezőbb piaci körülmények közt hozzák forgalomba az árukat, mint amelyek a behozatalkor érvényben vannak. Kiemelést érdemel a vámeljárások során nyújtott ügyfélelőnyök közt az aktív feldolgozás, amely munkahelyteremtő hatásával közvetett gazdasági élénkítő hatást is gyakorol.

Más kedvezmények egyszerűsítik a vámfizetést a végleges rendeltetéssel behozott nem közösségi árukra alkalmazott fő szabály szerinti vámfizetés esetéhez képest, illetve az ideiglenes eljárások adminisztratív terheit csökkentik. Utóbbiak a vámeljárásokon kívül a vámügyi intézkedések, illetőleg az árunyilatkozat-adás terén biztosított előnyöknél is megtalálhatók.

Ezen kedvezmények alkalmazhatósága közvetlenül vagy közvetett módon a gazdasági társaságok kockázati értékelésén is múlik. Az ügyfélelőnyök összességükben pedig a külkereskedelem előtt álló akadályok leépítését, a terhek csökkentését

36 UVK. 149. cikk. 
szolgálják, illetőleg a kereskedelmi könnyítések körében értelmezhetők, amelyek a külkereskedelem költségeit mérsékelik.

\section{IRODALOMJEGYZÉK}

Csaba Zágon (2012): Határellenőrzés kockázati értékelése: határátkelőhelyek kockázati profilja és ennek lehetséges eleme az elóértesítés. Magyar Rendészet, 12. évf. 1. sz. 69-77.

Csaba, Zágon (2018): Experiences and spread of risk analysis in the law enforcement. In Czene-Polgár Viktória - Zsámbokiné Ficskovszky Ágnes szerk.: Innováció, elektronizáció, tudásmenedzsment. Budapest, Magyar Rendészettudományi Társaság Vám- és Pénzügyőri Tagozat. 47-57.

Dézsi Zsolt - Zoltay Gergely (2016): Vámjogi ismeretek. Vám-, jövedéki- és termékdíj ügyintézök kézikönyve. Budapest, Saldo Kiadó.

Lux, Michael (2017): Útmutató az Uniós Vámkódexhez. Budapest, Magyar Vámügyi Szövetség.

Schramm, Hans-Joachim (2015): Who benefits most from AEO certification? An Austrian perspective. World Customs Journal, Vol. 9, No. 1. 59-68.

Suba László - Szendi Antal (2018): Az uniós vámjog vázlata. Budapest, Dialóg Campus Kiadó.

Suba László (2019): Az árumozgás-felügyelet elektronizálási folyamata a vámhatóságnál. In Zsámbokiné Ficskovszky, Ágnes szerk.: Biztonság, szolgáltatás, fejlesztés, avagy új irányok a bevételi hatóságok múködésében. Budapest, Magyar Rendészettudományi Társaság Vám- és Pénzügyőri Tagozat. 202-217. DOI: https://doi.org/10.37372/mrttvpt.2019.1.13

Szalayné Sándor Erzsébet (2003): Az Európai Unió közjogi alapjai. Budapest-Pécs, Dialóg Campus Kiadó. Wagner, Gert R. (2019) Schnelleinsteig Zoll für Export und Import 2019. 3. Auflage. FreiburgMünchen-Stuttgart, Haufe Group. DOI: https://doi.org/10.34157/9783648113486-35

\section{Jogforrások}

2006. évi XLI. törvény a vámeljárások egyszerúsítéséről és összehangolásáról szóló, Kiotóban, 1973. május 18-án kelt nemzetközi egyezmény Brüsszelben, 1999. június 26-án létrehozott Módosító Jegyzőkönyvének kihirdetéséről.

A Bizottság (EU) 2015/2447 végrehajtási rendelete (2015. november 24.) az Uniós Vámkódex létrehozásáról szóló 952/2013/EU európai parlamenti és tanácsi rendelet egyes rendelkezéseinek végrehajtására vonatkozó részletes szabályok megállapításáról (VA)

Az Európai Gazdasági Közösséget létrehozó Rómában 1957. március 25-én aláírt szerződés (római szerződés). Forrás: https://eur-lex.europa.eu/legal-content/HU/TXT/?uri=celex:11957E/TXT (2019. 09. 20.)

Az Európai Parlament és a Tanács 952/2013/EU rendelete (2013. október 9.) az Uniós Vámkódex létrehozásáról (UVK)

Európai Unió Tanácsának 2003/231/EK határozata az Európai Közösségeknek a vámeljárások egyszerűsítéséről és összehangolásáról szóló nemzetközi egyezmény (Kiotói Egyezmény) módosító jegyzőkönyvéhez való csatlakozásról (2003. március 17.) 


\section{ABSTRACT}

\section{Customer Benefits in the EU Customs Code}

SZENDI Antal

This study provides an insight into the benefits of the economic operators specified in the EU Customs Code. As it is commonly known, customs duties are tax liabilities which are payable when a product enters into the territory of the Union from another country. However, customs legislation does not always prescribe a specific obligation to pay. The customs burden is paid when the goods arrive in the internal market of the European Union, and it is of their final destination. However, in a significant part of the cases, the importation of goods is not the ultimate purpose. For instance, interim work processes often occur and, due to the absence of finality, there is no need to pay customs duties. The study explains such cases that are particularly benefitial to economic operators.

Keywords: EU Customs Code, public duties, import of goods, economic operators 